\title{
PENERAPAN HUKUM ADAT SEBAGAI SOLUSI KONFLIK ANTAR KAMPUNG DI KECAMATAN DOLO KABUPATEN SIGI (Tinjauan Hukum Islam)
}

\author{
Fadlun ${ }^{1}$, Gani Jumat ${ }^{2}$, Sitti Nurkhaerah ${ }^{3}$ \\ ${ }^{1}$ Student Faculty of Shariah IAIN Palu, \\ email: fadlun97@gmail.com \\ 2Lecturer Faculty of Shariah IAIN Palu, \\ email: gani.jumat@gmail.com \\ ${ }^{3}$ Lecturer Faculty of Shariah IAIN Palu, \\ email: nurkhaerah@iainpalu.ac.id
}

\begin{abstract}
This research examines the application of customary law as a solution to conflicts between villages in Dolo District, Sigi Regency. This research focuses on solving problems about how to apply customary law as a solution to conflicts between villages in Dolo District. This research method uses a qualitative approach, data collection techniques through observation, interviews or interviews and documentation, data analysis techniques used are data reduction, data presentation, data verification. Then check the validity of the data. What is found in this research is that the solution to prevent conflict in society must involve the roles of all elements, not only the Dolo District government, but the community itself, especially the facilitators, because the progress of an area cannot be separated from the participation of the youth in the area itself. Apart from that, there are obstacles to implementing customary law as a solution to conflicts between villages and what methods or approaches are used in implementing customary law.
\end{abstract}

Keywords : Conflict, Public, Young man, Between Villages

\begin{abstract}
Abstrak
Penelitian ini mengkaji tentang penerapan hukum adat sebagai solusi konflik antar kampung di Kecamatan Dolo, Kabupaten Sigi. Penelitian ini memfokuskan untuk menyelesaikan permasalahan tentang bagaimana penerapan hukum adat sebagai solusi konflik antar kampung di Kecamatan Dolo. Metode penelitian ini menggunakan pendekatan kualitatif, teknik pengumpulan data melalui observasi, interview atau wawancara dan dokumentasi, teknis analisis data yang digunakan adalah reduksi data, penyajian data, verifikasi data.kemudian melakukan pengecekan keabsahan data. Adapun yang ditemukan dalam penelitian ini adalah solusi untuk mencegah terjadinya konflik di masyarakat harus dilibatkan peran dari semua elemen, bukan hanya pemerintah Kecamatan
\end{abstract}


Dolo, tetepi masyarakat sendiri, khususnya pemudah, karenan kemajuan suatu daerah tidak lepas peran serta dari pemuda yang ada diderah itu sendiri. Selain itu, kendala-kendala penerapan hukum adat sebagai solusi konflik antar kampung.serta metode atau pendekatan apa yang digunakan dalam menerapkan hukum adat.

Kata kunci : Konflik, Masyarakat, Pemuda, Antar Kampung

\section{A. Pendahuluan}

Konflik sosial yang terjadi di dalam masyarakat menjadi bagian eskalasi massa yang sifatnya destruktif bahkan cenderung anarkis. ${ }^{1}$ Konflik selalu memiliki penyebab, ada konflik yang dipicu oleh faktor agama, sumber daya alam, akses ekonomi, politik dan lain sebagainya. Mencermati konflik sosial yang terjadi di Desa Kotarindau yang selalu terjadi dipicu oleh hal-hal sepeleh seperti saling ejek mengejek antar pemudah, perebutan lahan parkir, yang sebenarnya masih bisa ditempuh dengan jalan damai, namun penyelesaiannya sering ditempuh dengan jalan kekerasan.

Konflik bernuansa SARA yang pernah terjadi dan kini malah kembali marak di Indonesia juga menjadi bukti bahwa bangsa Indonesia kurang memiliki kesadaran multikultur. Sehingga penyelesaian konflik yang tidak menyentuh kepada aspek penyadaran, hanya seperti memadamkan api sekejap tetapi kemudian bisa kembali membara jika diterpa angin. Pemerintah dan aparat keamanan seringkali hanya mengedepankan aspek seremonial berupa tandatangan kesepakatan damai, jabat tangan, gandengan tangan tetapi tidak pernah mendalami aspek masalah terdalam yang menjadi sumber dan akar konflik. Mereka sering kali diabaikan untuk menyelesaian konflik melalui kajian dan pemetaan mendalam baik sumber, akar, pemicu hingga pada level actor sehingga yang muncul adalah seremoni belaka. Inilah yang menjadi latar belakang mengapa penelitian ini penting untuk dilakukan.

${ }^{1}$ Soejono Soekanto. Kedudukan dan Peranan Hukum Adat di indonesia. (Jakarta: Kurnia Esa, 1982), 5. 
Nasdian menyebut kelembagaan sebagai aspek kultural dan struktural. Secara kelembagaan segi kultural berkenaan norma dan nilai, sementara segi struktural menyangkut peranan sosial. Kultural maupun struktural adalah dua elemen yang saling berhubungan satu sama lain. ${ }^{2}$

Sangaji juga mengemukakan bahwa komunitas-komunitas masyarakat adat di Sulawesi Tengah bukanlah identitas yang terisolasi dan tidak pernah berubah, tetapi telah mengalami perubahan sedemikian rupa. Sejarah mereka yang panjang dalam migrasi, peralihan agama, dominasi politik oleh kekuatan politik di luar mereka, dan terintegrasi ke dalam ekonomi pasar. Komunitas semacam ini yang dianggap sebagai masyarakat adat harus dipahami sebagai entitas yang kompleks dan dinamis. Hukum adat di muka bumi ini senantiasa tumbuh, berkembang serta dipertahankan oleh masyarakat adatnya begitupun di Indonesia. Hal tersebut timbul dari suatu kebutuhan hidup yang nyata, cara hidup, dan pandangan hidup yang keseluruhannya merupakan kebudayaan masyarakat tempat hukum adat itu berlaku. Aturan dan nilai adat awalnya dibuat dan disesuaikan dengan kebutuhan serta konteks masyarakat adat itu sendiri. ${ }^{3}$

Konflik terjadi karena perbedaan ciri-ciri yang ada pada diri seseorang, keluarga, masyarakat bahkan tempat tinggal (lingkungan) misalnya kepandaian, pengetahuan, adat istiadat, keyakinan dan sebagainya. Dari hasil penelitian dan pengamatan yang dilakukan peneliti, bahwa konflik yang terjadi baik itu di lingkungan keluarga, masyarakat khususnya di Kecamatan Dolo yang ada beberapa tersebut dikarenakan kurangnya lapangan pekerjaan, minimya keterampilan masyarakat yang di akibatkan kurang kesadaran untuk mengenyam proses pendidikan, ditambah lagi faktor pendapatan warga yang tidak cukup untuk memenuhi kehidupan keluarganya. 
Dari penjelasan di atas, penelitian ini akan menyelesaikan permasalahan terhadap bagaimana penerapan hukum adat sebagai solusi konflik antar kampung di Kecamatan Dolo Kabupaten Sigi. Sehingga, tujuan yang mendasar penelitian adalah untuk mendeskripsikan serta menjelaskan penerapan hukum adat sebagai solusi konflik antar kampung di Kecamatan Dolo Kabupaten Sigi.

Metode yang digunakan dalam penelitian ini adalah penelitian kualitatif deskriptif dan data empiris diperoleh saat penelitian dilakukan. Ada dua hal penting yang sangat menonjol dalam penggunaan penelitian kualitatif yaitu deskripsi dan analisis. ${ }^{4}$ Maksudnya peneliti lebih menitikberatkan pada kegiatan penelitian di lokasi objek penelitian. Ini dimaksudkan agar peneliti dapat merasakan dan melihat langsung obyek yang akan diteliti dan melakukan komunikasi dan interaksi dengan sebagian sumber data secara lebih akrab. Sehingga dalam proposal ini, peneliti tidak membutuhkan hipotesis yang sifatnya menduga-duga hal-hal yang menyangkut.

\section{B. Pembahasan}

\section{Pengertian Konflik}

Konflik berasal dari kata kerja Latin configere yang berarti saling memukul. Secara sosiologis, konflik diartikan sebagai suatu proses sosial antara dua orang atau lebih (bisa juga kelompok) dimana salah satu pihak berusaha menyingkirkan pihak lain dengan menghancurkannya atau membuatnya tidak berdaya. ${ }^{5}$

Munculnya konflik tidak bisa terlepas dari kehidupan suatu masyarakat, karena konflik merupakan suatu fenomena yang tidak dapat dihilangkan dalam suatu interaksi sosial. Konflik hanya dapat dikendalikan dan diminimalisasikan saja, sehingga konfik yang timbul tidak sampai

${ }^{4}$ Soejono dan Abdurrahman, Metode Penelitian Suatu Pemikiran dan Penerapan, (Jakarta: Rineka Cipta, 2005), 2.

${ }^{5}$ Wirawan, Konfilk Dan Manajemen Konflik Teori, Aplikasi, Dan Penelitian (Jakarta: Salemba Humanika, 2010), 5. 
stadium lanjut yang mengancam kehidupan bermasyarakat, berbangsa dan bernegara.

Islam memiliki pandangan yang sama terhadap konflik. Meskipun Islam yang notabene lebih mengutamakan perdamaian, sesuai dengan makna kata Islam sendiri yakni "salam". Namun bukan berarti Islam tidak memberikan makna dan pandangan terhadap konsepsi koflik. Dalam agama Islam pemaknaan konflik bisa dalam bentuk yang lebih ramah dan damai. Dalam Islam konflik tidak harus difahami sebagai gejala yang destruktif, dan kontra-produktif, namun bisa menjadi gejala yang konstruktif bahkan produktif. Konflik merupakan bagian dari tabiat manusia yang telah dibawa oleh manusia dari sejak dia dilahirkan. ${ }^{6}$

Keberadaan konflik sebagai unsur pembawaan sangat penting dalam kehidupan manusia. Kehidupan tidak dapat berjalan dengan baik tanpa ada konflik. Manusia yang memiliki tuntutan serta keinginan yang beraneka ragam dan manusia akan selalu berusaha untuk memenuhi keinginan tersebut.

Allah swt. membekali nilai-nilai moral pada setiap makhluk dalam kepentingan-kepentingannya sendiri. Selagi konflik masih dibutuhkan oleh manusia, maka mereka pun dibekali oleh Allah dengan kemampuan untuk berkonflik, baik dalam fisik, roh maupun akalnya, dan sekaligus kemampuan untuk mencari solusinya. ${ }^{7}$

Dengan demikian, yang perlu diperhatikan adalah hikmah dibalik terjadinya konflik. Dalam Islam, konflik bukanlah sebagai tujuan namun lebih sebagai sarana untuk memadukan antara berbagai hal yang saling bertentangan untuk membebaskan kehidupan manusia dari kepentingan individual dan dari kejelekan-kejelekan, sehingga tidak membiarkan perbedaan-perbedaan itu menjadi penyebab adanya permusuhan. Karena sesungguhnya manusia berasal dari asal yang sama. 


\section{Penerapan Hukum Adat Sebagai Solusi Konflik Antar Kampung (Suatu Tinjauan Hukum Islam)}

Untuk dapat menyelesaikan konflik yang terjadi di masyarakat, tentunya harus diketahui penyebab konflik. Dengan mengetahui sebabnya, maka konflik diharapkan segera bisa diselesaikan. Dalam pandangan teori konflik bahwa masyarakat selalu dalam kondisi perubahan, dan setiap elemen dalam masyarakat memberikan sumbangan bagi terjadinya konflik di masyarakat. Dalam pandangan teori ini bahwa masyarakat disatukan oleh ketidakbebasan yang dipaksakan. Dengan demikian, posisi tertentu di dalam masyarakat mendelegasikan kekuasaan dan otoritas terhadap posisi yang lain.

Ada empat cara pokok mengatasi konflik. Berikut adalah keterangan singkat mengenai keempat cara tersebut:

a. Paksaan. Cara ini di lakukkan dengan memaksa para pihak yang bersenngketa untuk mengadakan perdamaian.

b. Arbitrasi. Kata arbitrasi berasal dari bahasa latin arbitratium,yang berarti keputasn wasit.Arbitrese merupakan prose untuk mengatasi konflik dengan melalui pihak tertentu, yaitu arbitrator.

c. Mediasi, Mediasi adalah cara penyelesaian konflik dengan meggunakan pihak ketiga yang memiliki hubungan baik dengan para pihak yang berkonflik.

d. Negosiasi. Negosiasi merupakan cara penyelesaiaan konflik atas inisiatif pihak-pihak yang berkonflik.Dalam prose ini,kedua pihak yang berkonflik melakukan pembicaraan dalam bentuk tawarmenawar mengenai syarat-syarat mengakhiri konflik. ${ }^{8}$

Berbeda dengan para teoritisi konflik di atas, Collins, seorang ahli sosiologi, lebih menekankan bahwa konflik lebih berakar pada masalah individual karena akar toretisnya lebih pada fenomenologis dan etnometodologi. Dia lebih memilih konflik sebagai fokus berdasarkan landasan yang realistik, karena konflik adalah proses sentral dalam kehidupan sosial. ${ }^{9}$ Kedua penyebab konflik tersebut terkesan terlalu rumit untuk dipahami dan kurang mengarah secara langsung pada tataran

${ }^{8}$ Yahya Harahap. Hukum Acara Perdata : tentang gugatan, persidangan, penyitaan, pembuktian, dan putusan pengadilan, (Jakarta: Sinar Grafika, 2005), 55.

76.

${ }^{9}$ Anwar Mulya, Manusia dan Hukum Kebudayaan di Indonesia, (Jakarta: Penerbit Djambatan.1998), 
konflik yang realistis. Namun demikian, secara umum penyebab konflik bisa disederhanakan sebagai berikut:

a. Konflik Nilai. Kebanyakan konflik terjadi karena perbedaan nilai. Nilai merupakan sesuatu yang menjadi dasar, pedoman, tempat setiap manusia menggantungkan pikiran, perasaan, dan tindakan. Yang termasuk dalam kategori ini adalah konflik yang bersumber pada perbedaan rasa percaya, keyakinan, bahkan ideologi atas apa yang diperebutkan.

b. Kurangnya Komunikasi. Kita tidak bisa menganggap sepele komunikasi antarmanusia karena konflik bisa terjadi hanya karena dua pihak kurang berkomunikasi. Kegagalan berkomunikasi karena dua pihak tidak dapat menyampaikan pikiran, perasaan, dan tindakan sehingga membuka jurang perbedaan informasi di antara mereka, dan hal semacam ini dapat mengakibatkan terjadinya konflik.

c. Kepemimpinan yang Kurang Efektif . Secara politis kepemimpinan yang baik adalah kepemimpinan yang kuat, adil, dan demokratis. Namun demikian, untuk mendapatkan pemimpin yang ideal tidah mudah. Konflik karena kepemimpinan yang tidak efektif ini banyak terjadi pada organisasi atau kehidupan bersama dalam suatu komunitas. Kepemimpinan yang kurang efektif ini mengakibatkan anggota masyarakat "mudah bergerak".

d. Ketidakcocokan Peran. Konflik semacam ini bisa terjadi kapan saja dan di mana saja. Ketidakcocokan peran terjadi karena ada dua pihak yang mempersepsikan secara sangat berbeda tentang peran mereka masing-masing.

e. Produktivitas Rendah. Konflik seringkali terjadi karena out put dan out come dari dua belah pihak atau lebih yang saling berhubungan kurang atau tidak mendapatkan keuntungan dari hubungan tersebut. Oleh karenanya muncul prasangka di antara mereka. Kesenjangan ekonomi di antara kelompok masyarakat, termasuk dalam konflik ini.

f. Perubahan Keseimbangan. Konflik ini terjadi karena ada perubahan keseimbangan dalam suatu masyarakat. Penyebabnya bisa karena faktor alam, maupun faktor sosial.

g. Konflik atau Masalah yang Belum Terpecahkan. Banyak pula konflik yang terjadi dalam masyarakat karena masalah terdahulu tidak terselesaikan. Tidak ada proses saling memaafkan dan saling mengampuni sehingga hal tersebut seperti api dalam sekam, yang sewaktu-waktu bisa berkobar. ${ }^{10}$

\footnotetext{
${ }^{10}$ Nadjemudin, DPRD Sigi Dorong Lembaga Adat Atasi Konflik, dikutip dari http://www. antarasulteng.com/berita/987/dprd-sigi-dorong-lembaga-adat-atasi-konflik diakses tanggal 14 Mei 2016
} 
Tujuh penyebab konflik di atas adalah penyebab yang sifatnya umum, dan sebenarnya masih bisa diperinci lebih detail lagi. Namun demikian, jika mencermati konflik-konflik yang terjadi khususnya masyarakat Indonesia akhir-akhir ini, paling tidak ada salah satu penyebab seperti di atas. Dengan mengetahui penyebab terjadinya konflik bisa berharap bahwa konflik akan bisa dikelola, dan diselesaikan dengan baik.

Setelah mengetahui penyebab terjadinya konflik, kini bisa dimulai untuk mencoba berbagai alternatif teoretis untuk menyelesaikan konflik yang tejadi. Secara umum, untuk menyelesaikan konflik dikenal beberapa istilah, yakni:

a. Pencegahan konflik; pola ini bertujuan untuk mencegah timbulnya kekerasan dalam konflik,

b. Penyelesaian konflik; bertujuan untuk mengakhiri kekerasan melalui persetujuan perdamaian,

c. Pengelolaan konflik; bertujuan membatasi atau menghindari kekerasan melalui atau mendorong perubahan pihak-pihak yang terlibat agar berperilaku positif;

d. Resolusi konflik; bertujuan menangani sebab-sebab konflik, dan berusaha membangun hubungan baru yang relatif dapat bertahan lama di antara kelompok-kelompok yang bermusuhan,

e. Transformasi konflik; yakni mengatasi sumber-sumber konflik sosial dan politik yang lebih luas, dengan mengalihkan kekuatan negatif dari sumber perbedaan kepada kekuatan positif. ${ }^{11}$

Berikut ini beberapa strategi-strategi untuk mengakhiri konflik. Setidaknya ada sepuluh strategi untuk mengakhiri konflik, yakni abandoning atau meninggalkan konflik, avoiding atau menghindari, dominating atau menguasai, obliging atau melayani, getting help atau mencari bantuan, humor atau bersikap humoris dan santai, postponing atau menunda, compromise atau berkompromi, integrating atau mengintegrasikan, problem solving atau bekerjasama menyelesaikan masalah. ${ }^{12}$ Sementara itu, untuk menyelesaikan konflik, secara teoretis

\footnotetext{
${ }^{11}$ Rangi, Fery, Peran dan Politisasi Lembaga Adat di Kabupaten Sigi, ed. VII, (Studi kasus Lembaga Adat di Kulawi, Jurnal Sejarah dan Budaya, edisi No. 7 Tahun VII, 2012), 27-32. 1982). 29

${ }^{12}$ Soerjono Soekanto, Kedudukan dan Peranan Hukum Adat di indonesia, (Jakarta: Kurnia Esa,
} 
ada banyak sekali model, namun dalam tulisan ini hanya akan di sajikan beberapa model saja. Di antaranya adalah sebagai berikut: ${ }^{13}$

Pertama, model penyelesaian berdasarkan sumber konflik. Dalam model ini, untuk bisa penyelesaian konflik dituntut untuk terlebih dahulu diketahui sumber-sumber konflik: apakah konflik data, relasi, nilai, struktural, kepentingan dan lain sebagainya. Setelah diketahui sumbernya, baru melangkah untuk menyelesaikan konflik. Setiap sumber masalah tentunya memiliki jalan keluar masing-masing sehingga menurut model ini, tidak ada cara penyelesaian konflik yang tunggal.

Kedua, model Boulding. Model Boulding menawarkan metode mengakhiri konflik dengan tiga cara, yakni menghindar, menaklukkan, dan mengakhiri konflik sesuai prosedur. Menghindari konflik adalah menawarkan kemungkinan pilihan sebagai jawaban terbaik. Akan tetapi, harus diperhatikan bahwa ini hanya bersifat sementara agar kedua pihak dapat memilih jalan terbaik mengakhiri konflik. Menaklukkan adalah pengerahan semua kekuatan untuk mengaplikasikan strategi perlawanan terhadap konflik. Mengakhiri konflik melalui prosedur rekonsiliasi atau kompromi adalah metode umum yang terbaik dan paling cepat mengakhiri konflik.

Ketiga, model pluralisme budaya. Model pluralisme budaya, dapat membantu untuk melakukan resolusi konflik. Misalnya, individu atau kelompok diajak memberikan reaksi tertentu terhadap pengaruh lingkungan sosial dengan mengadopsi kebudayaan yang baru masuk. Inilah yang kemudian disebut sebagai asimilasi budaya. Selain asimilasi, faktor yang bisa membuat kita menyelesaikan konflik adalah akomodasi. Dalam proses akomodasi, dua kelompok atau lebih yang mengalami konflik harus sepakat untuk menerima perbedaan budaya, dan perubahan penerimaan itu harus melalui penyatuan penciptaan kepentingan bersama.

${ }^{13}$ lbid, 46. 
Keempat, model intervensi pihak ketiga. Dalam model ini ada beberapa bentuk, yakni coercion, arbitrasi, dan mediasi. Coercion adalah model penyelesaian konflik dengan cara paksaan, di mana masingmasing pihak dipaksa untuk mengakhiri konflik. Arbitrasi adalah penyelesaian konflik dengan cara mengambil pihak ketiga untuk memutuskan masalah yang terjadi, dan keputusan pihak ketiga harus dipatuhi oleh masing-masing pihak. Sementara itu, mediasi berarti pihak ketiga hanya berfungsi untuk menjembatani penyelesaian konflik yang terjadi dalam masyarakat.

Dari keempat model peneyelesaian di atas hanyalah sebagian dari berbagai model penyelesaian konflik yang ada. Masih banyak lagi modelmodel penyelesaian konflik yang lain. Namun demikian, satu hal yang harus diingat adalah setiap konflik memiliki kompleksitas yang berbedabeda sehingga tidak bisa mengambil salah satu model untuk langsung diterapkan begitu saja untuk menyelesaikannya. Harus dipahami secara sungguh-sungguh kerumitan dan kompleksitas konflik yang akan dicari jalan keluarnya.

Selain model-model penyelesaian konflik yang sudah ada secara teoretis di atas, namun harus diingat juga bahwa bangsa Indonesia adalah bangsa besar yang memiliki keragaman budaya. Setiap budaya memiliki kearifan-kearifan tersendiri dalam menyikapi permasalahan hidup yang dihadapi, termasuk di dalamnya kearifan dalam menyelesaikan konflik. Kearifan-kearifan seperti inilah yang sering disebut sebagai kearifan lokal (local wisdom). ${ }^{14}$

Konflik-konflik yang tengah berlangsung di wilayah nusantara, baik konflik vertikal maupun konflik horisontal telah menimbulkan gangguan terhadap ketahanan bangsa dan negara karena cenderung melebar ke aspek-aspek kehidupan nasional yang lain, di antaranya gejala pudarnya rasa persatuan dan kesatuan bangsa pada sebagian warga Indonesia. Ciri

${ }^{14}$ Abdurrahman, Kedudukan Hukum Adat dalam Rangka Pembangunan Nasional, (Bandung: Alumni, 
kemajemukan bangsa dan wilayah negara kita yang berbentuk kepulauan harus diterima sebagai kenyataan objektif yang mengandung potensi konflik.

Cara penyelesaian konflik lebih tepat jika menggunakan modelmodel penyelesaian yang disesuaikan dengan kondisi wilayah serta budaya setempat. Ideal apabila penyelesaian tersebut dilakukan atas inisiatif penuh dari masyarakat bawah yang masih memegang teguh adat lokal serta sadar akan pentingnya budaya lokal dalam menjaga dan menjamin keutuhan masyarakat.

Tradisi dan kearifan lokal yang masih ada serta berlaku di masyarakat, berpotensi untuk dapat mendorong keinginan hidup rukun dan damai. Hal itu karena kearifan tradisi lokal pada dasarnya mengajarkan perdamaian dengan sesamanya, lingkungan, dan Tuhan. Hal yang sangat tepat menyelesaikan konflik dengan menggunakan adat lokal atau kearifan lokal karena selama ini sudah membudaya dalam masyarakat. Oleh karena kearifan lokal adalah sesuatu yang sudah mengakar dan biasanya tidak hanya berorientasi profan semata, tetapi juga berorientasi sakral sehingga pelaksanaannya bisa lebih cepat dan mudah diterima oleh masyarakat.

\section{Kendala dalam Penerapan Hukum Adat Sebagai Solusi Konflik Antar Kampung (Suatu Tinjauan Hukum Islam)}

Dari sudut pandang sejarah dan budaya, masyarakat Indonesia adalah masyarakat yang agraris dan hingga saat ini industrialisasi sudah menjadi tuntutan dari masyarakat di era modernisasi, namun tinggal sebagian kecil dari masyarakat Indonesia yang masih mempertahankan hukum adat sebagai hukum yang berlaku dalam kehidupan sehari - hari.

Ada empat syarat yuridis diberlakukan bagi eksistensi hukum adat dan ini juga merupakan salahsatu kendala yaitu:

a. Sepanjang masih hidup

Maksudnya, kita tidak semata-mata melakukan pengamatan dari luar, melainkan juga dari dalam, dengan menyelami perasaan masyarakat 
setempat (pendekatan partisipatif). Selama hukum adat masih berkembang dalam masyarakat sebagai hukum sehari-hari, maka hukum adat ini dapat digunakan hakim sebagai salah satu pertimbangan saat memutuskan perkara atau masalah.

b. Sesuai dengan perkembangan masyarakat

Maksudnya, Syarat ini mengandung resiko untuk memaksakan kepentingan raksasa atas nama perkembangan masyarakat. Tidak memberi peluang untuk membiarkan dinamika masyarakat setempat berproses sendiri secara bebas. Ini berarti, hukum adat harus sesuai dengan hukum yang berkembang dalam masyarakat dan bukan hukum yang berkembang karena adanya perubahan yang dilakukan oleh sekelompok atau pembangunan ataupun gerakan sosial masyarakat.

c. Sesuai dengan prinsip NKRI. Kelemahan paradigma ini melihat NKRI dan masyarakat adat sebagai dua antitas (wujud) yang berbeda dan berhadap-hadapan.

d. Diatur dalam undang-undang

Maksudnya, pengertian diatur dalam undang- undang berarti bahwa pengaturan masyarakat hukum adat tidak harus dengan satu undangundang tersendiri, tetapi dapat diatur dalam suatu undang-undang yang terkait, misalnya undang-undang tentang pemerintahan daerah. Di dalam undang- undang tersebut, di samping kriteria kesatuan masyarakat hukum adat, juga harus diatur hak-hak masyarakat hukum adat, lembaga yang berwenang menentukan serta bagaimana mekanisme penentuannya. ${ }^{15}$

Selain itu yang menjadi kendala dalam penerapan hukum adat ialah kehidupan masyarakat yang berdasarkan adat kini hanya mengakar dalam kehidupan generasi tua saja. Ditambah lagi dengan perubahan zaman yang dibarengi dengan kemodernisasi, yang telah menyisihkan keseharian adat dari kehidupan masyarakat, khususnya kaum muda selain itu kuatnya pengaruh Agama, dan tingkat pendidikan yang membawa transformasi pengetahuan masyarakat, dan akulturasi budaya

${ }^{15}$ Ibid, 99. 
yang didukung transportasi dan teknologi transportasi yang dibawa oleh penduduk pendatang. Faktor faktor tersebut kemudian menjadikan apa yang dinamakan adat tergerus dan tergantikan oleh nilai-nilai baru. Hal itu membuat lembaga adat yang selama ini membuat serta mensosialisasikan aturan yang dibuatnya sendiri terkadang membutuhkan kerjasama dari pihak lain dalam upaya menegakan aturan yang telah dibuat. yang sering terjadi dalam penyelesaian konflik melalui kepala adat adalah faktor internal yang disebabkan oleh saksi tidak mau menjadi saksi, ketidakjelasan konflik dan ketidakjelasan siapa actor dibalik konflik yang terjadi. Selain itu faktor penghambat lainnya adalah faktor eksternal yang berasal dari pihak ketiga baik yang berasal dari keluarga salah satu pihak yang bersengketa maupun pihak ketiga di luar para pihak yang bersengketa.

\section{Penerapan Hukum Adat sebagai Solusi Konflik Antar Kampung di Kecamatan Dolo, Kabupaten Sigi}

Banyak cara yang telah dilakukan pemerintah dalam menyelesaikan konflik yang terjadi, namun konflik selalu terjadi dikarenakan dendam yang tidak perna habis diantara pemudah.

Berdasarkan hasil wawancara yang dilakukan nampak jelas bahwa berbagai upaya dalam usaha menyelesaikan konflik di daerah Kabupaten Sigi khususnya di kecamatan dolo telah banyak dilaksanakan. Hanya saja hasil dari semua bentuk penyelesaian konflik tersebut tampak tidak efektif. Penyelesaian konflik yang nuansanya kebanyakan seremonial dan hanya sebatas pada mediasi serta resolusi konflik tetapi tidak dibarengi dengan upaya penciptaan perdamaian melalui pembangunan menyebabkan upaya ini tidak juga berhasil.

Kami selaku pemerintah Kecamatan Dolo yang bekerja sama dengan pemerintah desa telah melakukan berbagai macam cara untuk mencegah terjadinya konflik, misalnya dengan cara sosialisasi kepada semua masyarakat khususnya pemudah disemua desa yang ada di kec. Dolo. tentang penerapan hukum adat sebagai solusi konflik, maka kami pemerinta daerah serta mengundang kepolisian, pemerintah desa, tokoh masyrakat dan 
tokoh pemudah. Untuk mencari solusi. Dan hasilnya 2 tahun terahir ini konflik anata pemudah desa yang terjadi dikecamatan dolo, khususnya di beberapa desa yang sering terjadi konflik mulai redah sedikit demi sedikit, seperti desa tulo, karawana, langaleso dan kotarindau sudah mulai berkurang. ${ }^{16}$

Hasil penelitian menunjukkan bahwa penyelesaian konflik yang dilakukan oleh pemerintah baik kabupaten ataupun kecamatan yang bekerjasama dengan aparat keamanan masih sebatas penyelesaian berdasarkan pendekatan hukum dan lebih konvensional. Pertemuan dan mediasi yang dibangun oleh aparat pemerintahan nampaknya hanya melibatkan pihak-pihak bertikai dengan orang tua masing-masing. Dengan perspektif semacam ini pemerintah daerah menganggap masalah konflik di Sigi hanya sebagai kriminalitas biasa sehingga menggantungkan proses penyelesaiannya di depan kepolisian dan hanya melibatkan kedua belah pihak. Cara pandang semacam itu menunjukkan penyederhanaan terhadap apa yang terjadi di daerah tersebut. Selain itu anggapan atas adanya provokator dalam artian pihak-pihak yang menjadi pendorong terjadinya konflik berkepanjangan menunjukkan bahwa introduksi kekerasan di daerah ini berlangsung melalui tangantangan pihak luar. Meski dugaan ini agak sumir, tetapi jika ditelisik lebih jauh dari perspektif dan kacamata keamanan wilayah, dugaan adanya pihak-pihak yang memainkan konflik di Sigi cukup beralasan. Ada rentetan peristiwa dan kejadiankejadian politik yang seringkali mengiringinya.

Dalam hal ini pelibatan kelembagaan adat menjadi penting, terutama di dalam menetapkan sanksi yang diterapkan bagi pelanggar kesepakatan. Tentu saja masalah utama yang dihadapi adalah bagaimana peran kelembagaan adat dalam penyelesaian konflik Berikut ini beberapa contoh hukum adat yang diberlakukan dibeberapa desa yang ada di Kecamatan Dolo yaitu:

Beberapa sanksi yang disebutkan dalam hukum adat yaitu antara lain ditenggelamkan, dibuang dari kampung, dikucilkan dari masyarakat, dan mengganti atau membayar denda berupa hewan serta perlengkapan adat. Dalam Atura Nuada (hukum adat)

${ }^{16}$ Kamus lawi, Camat Dolo, "wawancara", diruangan Camat Dolo pada tanggal 5 Agustus 2016 
terdapat hukuman bagi pelanggar norma adat dengan kategori berat (sala kana), pelanggar dengan kategori sedang (sala baba), dan pelanggar norma adat kategori ringan (sala mbivi). Adapun bentuk sanksi adat yang disepakati, antara lain mulai dari diusir dari kampung halaman, hingga membayar denda berupa hewan ternak atau benda berharga lainnya. ${ }^{17}$

Semua hasil perjanjian hukum adat yang telah disepakati telah disosialisasikan di semua desa yang ada di kecamatan dolo serta selanjutnya kekecamatan lainnya yang sering terlibat konflik seperti kecamatan marawola, dan gumbasa. Dengan demikian hukum nuada ini mulai diberlakukan secara umum disemua wilayah kabupaten sigi.

\section{Apa Unsur Pembentukan Adat di Kecamatan Dolo?}

Jika kita melihat sejarah bahwa unsur pembentukan hukum adat secara umum di kabupaten sigi dan secara khusus di kecamatan dolo tidaklah lepas dari bentuk-bentuk pelanggaran yang kemudian diatur dalam hukum adat itu sendiri, contoh, perzinahan, pencurian, penganiayaan, kekerasan dalam rumah tangga, penghinaan, penipuan, hingga pencemaran nama baik.

\section{Siapa yang Menerapkan Hukum Adat di Kecamatan Dolo?}

Banyak upaya telah dilakukan aparat keamanan, pemerintah dan masyarakat sendiri untuk mengakhiri seringnya kejadian bentrok tersebut. Pemerintah daerah selalu melakukan pertemuan dengan warga yang terlibat bentrok dan selanjutnya ada penandatanganan di secarik kertas berintikan kesepakatan damai. Namun beberapa hari kemudian bentrok serupa terjadi di tempat yang sama dengan melibatkan orang-orang yang itu-itu juga.Aparat keamanan sering dituding lambat tiba di lokasi bentrok sehingga tawuran telah merembet ke mana-mana. Petugas keamanan juga kerap dituding kurang tegas karena melepaskan pelaku bentrok yang telah ditangkap. Padahal polisi berkali-kali mengancam akan menindak tegas pelaku bentrok yang kedapatan membawa senjata tajam atau senjata api rakitan.

${ }^{17}$ Jamanudin, anggota adat, "wawancara", diwawancarai pada tanggal 5 Agustus 2016 
Terus berlangsungnya bentrok antarwarga, tentu saja membuat pemerintah, tokoh masyarakat dan aparat keamanan berpikir keras untuk mengakhirinya. Maka peran hukum adat sangat dibutuhkan dalam rangka mengurangi terjadinya bentrok antarwarga dan tindakan kriminalitas di masyarakat.

Sebenarnya hukum dan sanksi adat itu bertujuan menjunjung kearifan lokal di Kecamatan Dolo yang merupakan salah satu daerah rawan terjadinya konflik. Selain itu, hal tersebut juga bertujuan untuk menegakkan budi pekerti dan menghindari tindakan tak terpuji lainnya. Akan tetapi kami peran dari sanksi adat tersebut mulai pudar karena hukum yang diberlakukan yaitu hukum uud dasar $1945 . .^{18}$

Dalam wawancara lain anggota adat menginginkan agar pemerinta lebih menekankan untuk ditegakkan, mengingat peran adat sangat berpengaru, karena hukum adat yang ada di Kecamatan Dolo belum diterapkan secara menyeluruh hanya bebepara desa yang menegakan hukum adat tersebut yaitu Desa Karawana, Desa Soulowe dan Desa Kotarindau.

Kami selaku pemerintah Desa Karawana menerapkan sanksi adat yang ada serta menjunjung tinggi nilai-nilai adat yang ada. Dengan cara menegakan sanksi tersebut ketika ada warga saya yang memulai atau menghasut, dan sanksi adat yang kami tegakan bukan hanya persoalan konflik akan tetapi persoalan perzinaan, pencurian ini kami tegakan dengan sanksi membayar denda yang disesuaikan dangan kerugian. ${ }^{19}$

Dari hasil penelitian bahwa ke 3 desa tersebut menerapkan hukum adat yang berlaku, akan tetapi sifatnya hanya tingkat desa, salah satu hukum ada yang mereka terapkan yaitu ketika terjadinya konflik. Yang mana ketika ada warga masyarakat yang memulai membuat keributan akan didenda dengan 2 ekor kambing jantan. Akan tetapi masyarakat lebih menekankan sistem kekeluargaan dalam menyelesaikan konflik.

Kami meniginkan agar pemerintah kecamatan dolo untuk menegakan hukum dan sanksi adat diberlakukan secara menyeluruh dikecamatan dolo, mengingat konflik yang terjadi nantinya. ${ }^{20}$

\footnotetext{
${ }^{18}$ Jamanudin, anggota adat "wawancara”, tanggal 5 Agustus 2016

${ }^{19}$ Rahman, kepala desa karawana "wawancara", tanggal 5 Agustus 2016

${ }^{20}$ Jamanudin, anggota adat "wawancara", tanggal 5 Agustus 2016
} 


\section{Pendekatan Apa yang Digunakan dalam Menerapakan Hukum Adat di Kecamatan Dolo?}

Konflik yang terjadi ditengah-tengah masyarakat kecamatan dolo sudah menjadi hal yang biasa terjadi, konflik hampir dibeberapa desa yang ada sering mengalami konflik diantaranya desa kabobona, kotarindau, langaleso, kotapulu, potoya, solowe, karawana, dan desa tulo. Konflik yang terjadi hanya bergilir di desa-desa tersebut.

Untuk mencegah terjadinya konflik perlu diadakanya pendekatan yaitu dengan pendekatan adat dan keagamaan. Secara umum kepada masyarakat, khususnya pemudah dengan cara mengadakan dialog dengan pemuka-pemuka adat, tokoh agama, kepolisian dan pemerintah desa yang ada di kecamatan dolo guna menghasilkan kesepakatan yang bertujuan untuk penyelesain konflik, berupa sanksi-sanksi yang akan diterimah. Selain itu secara keagamaan kami selaku pemerintah menganjurkan untuk melakukan hal-hal yang positif misalnya megikuti majelis ta'lim dan melakukan kegiatan-kegiatan yang sifatnya religius. ${ }^{21}$

Banyak langka-langka yang telah ditempu pemerintah kecamatan dan pemerintah desa untuk menyelesaikan konflik yang terjadi, dianatara langka-langka tersebut yaitu mengadakan pertemuan dengan mengundang seluruh tokoh-tokoh yang berpengaru didesa tersebut, aparat keamanan, dan pemudah-pemudah yang ada didesa tersebut. Untuk mencarikan solusi agar konflik yang terjadi tidak menyebar lebih luas dan mengakibat korban jiwa. Selain itu tujuan pertemuan tersebut untuk mengambil keputusa tegas,apabila nantinya terjadi konflik maka pihak yang memulai akan ditindak tegar oleh aparat kemanan dan pemerintah melalui hukum adat yang telah disepakati dalam pertemuan. semua desa tidak akan membantu mereka yang melakukan tawuran.

Kurangnya kesadaran akan pendidkan, menyebabkan anak akan mudah putus asa, akibatnya anak tidak memiliki pengetahuan yang cukup untuk memilih mana yang baik dan mana yang buruk bagi dia, untuk mencegah terjadinya konflik/tawuran antar pemuda khususnya di kecamatan dolo diperlukan kesadaran dari semua pihak bahwa tawuran

${ }^{21}$ Soulowe, Kapala Desa "wawancara”, kantor desa, tanggal 7 Agustus 2016 
yang semakin berlarut akan memberikan dapak yang negatif terhadap perkembangan baik itu pendidikan, ekonomi, sosial dan politik.

Seiring dengan berlanjutnya krisis tersebut, akhirnya pemerintah mengambil kebijakan yang dianggap mampu menjadi salah satu alternatiff yang dapat menetralisir gejolak diatas, dengan melahirkan kembali konsep lama pembangunan ekonomi kerakyatan. Kebijakan ini pada gilirannya diharapkan dapat merubah watak, budaya dan integritas bangsa dalam rangka menuju sebuah kehidupan yang modern. Akan tetapi, ide untuk mewujudkan modemisasi ditengah heterogenitas budaya bila tetap dengan pola memaksakan kehendak tersebut sudah barang tentu akan menyebabkan timbulnya konflik yang tidak akan dapat dihindarkan.

Hal ini dikarenakan sistem sosial dan sistem budaya setiap masyarakat yang sedang "berkembang" merupakan suatu ajang (medan) pertempuran yang abadi, di mana kekuatan modernitas dan tradisi bertemu. Pada akhirnya, konflik ini akan melahirkan keteganganketegangan, ketidak mufakatan dan ketidak seimbangan diantara individu atau kelompok yang semula bersatu, mufakat dan seimbang (equilibrium).

\section{Kendala yang Menghambat Penerapan Hukum Adat di Kecamatan}

\section{Dolo?}

Secara khusus setiap desa dikabupaten sigi memiliki hukum adat istiadat yang berbeda-beda namun secara umum memiliki garis besar atau persamaan dalam beentuk sanksi atau peraturan lainya.

Selama ini masih banyak masyarakat yang kurang mematuhi hukum positif (misalnya perdes) sehingga kami selaku pemerinta desa penerapan hukum adat dinilai salah satu langka tepat untuk mengurangi perbuatan tak terpuji ditengah masyarakat. Selain itu Hukum dan sanksi adat sebenarnya ditanah kaili sebenarnya juga telah berlaku sebelum masuknya agama atau sebelum penjajahan bangsa asing di sulawesi tengah. Sehingga Di harapkan semua lapisan masyarakat, pemerintah dan aparat keamanan berharap penerapan hukum adat itu bisa menciptakan kerukunan antar warga. ${ }^{22}$

22Jamanudin, anggota adat "wawancara", tanggal 5 Agustus 2016 
Dalam kasus-kasus konflik kekerasan di Kecamatan Dolo, rangkaian penyelesaian konflik kekerasan tidak diikuti oleh penegakan hukum yang tegas dan berkeadilan ditandai dengan munculnya pandangan masyarakat di kedua kelompok yang menganggap bahwa dalam berbagai kasus kekerasan tidak ada pelaku yang ditindak secara adil bahkan ada upaya untuk memberikan perlindungan terhadap pelaku yang akan ditindak karena adanya jaminan dari pihak-pihak tertentu terhadap pelaku. Masyarakat menengarai bahwa hukum dan sanksi adat tidak ditegakan secara menyeluruh di kecamatan dolo. Dan di tambah lagi sikap polisi tidak memahami penegakan hukum yang bersifat afirmativ (keberpihakan terahadap kasus yang bersifat khusus). Aparat juga seringkali dinilai telah melakukan pembiaran atas keadaan yang didasarkan pada tidak konsistenan menjalankan Maklumat tentang Larangan Membawa Senjata Tajam dan Benda-Benda Berbahaya Lainnya, hal itu dibuktikan dengan terjadinya kasus kekerasan yang berulang-ulang. Tidak ada pemberian efek jera terhadap para pelaku kekerasan.

Selain itu yang menjadi kendala dalam penegakan hukum dan sanksi adat adalah kesadaran masyarakat yang minim, kurangnya sosialisasi tentang adat itu sendiri kepada masyarakat, tentang pentingnya penegakan adat, kurangnya kerja sama antara pemerintah kecamatan dan tokoh-tokoh adat yang ada di setiap desa.

\section{Penutup}

Dari uraian di atas, maka dapat diambil kesimpulan bahwa hasil analisis menunjukkan bahwa akar konflik kekerasan yang bernuansa konflik antardesa dan antar kampung yang selama ini terjadi di Kabupaten Sigi adalah ketidakjelasan batas wilayah antar desa dan antar kampung sebab dilatar belakangi sejarah, transformasi kekerasan yang berlangsung dari generasi ke generasi berikutnya, rendahnya penegakan hukum aparat dalam menyelesaikan persoalan kriminalitas biasa yang melibatkan personal, tingginya angka pengangguran, terjadinya pergeseran skala 
konflik kekerasan yang sifatnya personal menuju konflik komunal, kurang tersedianya ruang publik sebagai ruang akspresi generasi muda serta kurangnya pembinaan generasi muda untuk kegiatan yang lebih produktif, dan bias informasi dan distorsi informasi, dan adapun upaya penyelesaian konflik yang selama ini ditempuh melalui upaya rekonsiliasi dengan menempuh jalur pertemuan formal dengan melibatkan tokoh-tokoh masyarakat dan pemerintahan setempat tidak dapat menyelesaikan konflik yang terjadi antar desa dan antar kampung. Meski demikian salah satu model penyelesaian konflik yang dianggap cukup efektif adalah dengan menggunakan pendekatan adat, bentuknya adalah kesepakatan damai dengan menetapkan sanksi adat yang akan diterapkan kepada pihak-pihak yang melanggar kesepakatan. Model ini bisa berhasil dengan syarat kelembagaan adat di setiap desa di Kabupaten Sigi harus aktif dan keanggotaan atau pemangku adatnya adalah tokoh yang memiliki kharisma dan paling dipatuhi oleh warga dan sebisa mungkin terbebas dari determinan politik di Kabupaten Sigi.

\section{Daftar Pustaka}

Abdurrahman, Kedudukan Hukum Adat dalam Rangka Pembangunan Nasional, Bandung: 1978.

Anwar, Mulya, Manusia dan Hukum Kebudayaan di Indonesia. Jakarta: Penerbit Djambatan.1998

Bushar, Muhammad, Asas - Asas Hukum Adat, Suatu Pengantar, cet. II, Jakarta: Pradya Paramitha, 2002.

Daud Ali, Muhamad, Hukum Islam: Pengantar Tata Hukum Islam di Indonesia, Jakarta: Rajawali Press, 2003.

Departemen Pendidikan dan Kebudayaan, Kamus Besar Bahasa Indonesia, cet. VIII, Jakarta: Balai Pustaka, 1996.

Dewi, Wulansari, Hukum Adat Indonesia: Suatu Pengantar. Bandung: PT Refika Aditama, 2012.

Fery , Rangi, Peran dan Politisasi Lembaga Adat di Kabupaten Sigi, ed. No. VII, (Studi Kasus Lembaga Adat di Kulawi), Jurnal Sejarah dan Budaya, 2012. 
Komariah, D. Satori, Metodologi Penelitian Kualitatif, Bandung: Alfabeta, 2010.

Mardalis, Metode Penelitian: Suatu Pendekatan Proposal, Jakarta: Bumi Aksara, 2009.

Matthew B., Miles, A.Michael Huberman, Analisis Data Kualitatif Metode Baru, cet.I, Jakarta: UI Press, 1992.

Nadjemudin. "DPRD Sigi Dorong Lembaga Adat Atasi Konflik" dikutip dari http://www. antarasulteng.com/berita/987/dprd-sigi-doronglembaga-adat-atasikonflik diakses tanggal 14 Mei 2016

Nasution. S, Metode Research Penelitian IImiah, cet. VII, Jakarta: Bumi Aksara, 2004.

Soejono Soekanto, Kedudukan dan Peranan Hukum Adat di indonesia. Jakarta: Kurnia Esa, 1982.

Soejono, Abdurrahman, Metode Penelitian Suatu Pemikiran dan Penerapan, Jakarta: Rineka Cipta, 2005.

Suharsimi, Arikunto, Prosedur Penelitian Suatu Pendekatan Praktik, Jakarta: Rineka Cipta, 2002

Surahmad, Winarno, Pendekatan dalam Proses Belajar Mengajar Bandung: PT. Remaja Rosda Karya 1978.

Wirawan, Konfilk Dan Manajemen Konflik Teori, Aplikasi, Dan Penelitian, Jakarta: Salemba Humanika, 2010

Yahya, Harahap, Hukum Acara Perdata : Tentang Gugatan, Persidangan, Penyitaan, Pembuktian, dan Putusan Pengadilan. Jakarta: Sinar Grafika, 2005. 